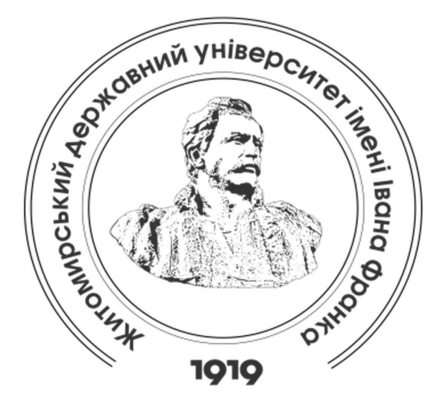

Zhytomyr Ivan Franko State University Journal. Pedagogical Sciences. Vol. 2 (101)

Вісник Житомирського державного університету імені Івана Франка. Педагогічні науки. Вип. 2 (101)

ISSN (Print): 2663-6387

ISSN (Online): 2664-0155

\title{
UDC 378.172 \\ DOI 10.35433/pedagogy.2(101).2020.62-73 \\ ACMEOLOGICAL PRINCIPLES OF HEALTH-PRESERVING COMPONENT FORMATION OF PROFESSIONAL PHYSICAL READINESS OF AGRICULTURAL SPECIALTIES STUDENTS
}

\section{A. V. Sakhnenko*}

The greatest value under fundamental human rights is one's life and health. The formation process foundations of harmoniously developed personality of the future specialist of the agroindustrial sector are laid in higher education. Its fundamental aspects are: good health, negative attitudes towards bad habits, the healthy lifestyle formation, achieving high and sustainable performance through exercise and sports. And that is why the acmeological component of health formation and preservation is especially important, because it acquires the deeper meaning in the context of solving modern society problems and, above all, human development, physical capabilities, spiritual potential and more. Recognized experts in the field of developmental psychology and acmeology pay the great attention to the human health state, which, of course, depends on harmonious personality formation and its "acme" achievement, its development peak.

The presented article considers acmeological principles of professionally oriented physical education of agricultural specialties students. The professional physical fitness structure of agricultural industry specialists is determined, which includes cognitive, physical and healthpreserving components.

However, 100 agricultural specialties students took part in the pedagogical experiment.

Gennadiy Leonidovych Apanasenko's method was used to determine the level of students' physical health. The study revealed a positive effect of the acmeological component of professionally oriented physical education on the health-preserving component formation of professional physical fitness of agricultural specialties students. The average somatic health index in the experimental group improved by 9,1 points and was qualitatively consistent with the average level of physical health. At the final study stage, students with low and below average physical health were not found among the experimental group.

Key words: acmeology, health, acmeological principles, technology, level, indicator, professionally oriented, professional physical fitness, component, health-preserving, agricultural specialties students.

\footnotetext{
${ }^{*} \mathrm{PhD}$ Student

(Sumy State Pedagogical University named after A. S. Makarenko) anna1179kr@ukr.net
}

ORCID: 0000-0002-8084-3897 


\section{АКМЕОАОГІЧНІ ЗАСАДИ ФОРМУВАННЯ ЗДОРОВ'ЯЗБЕРЕЖУВАИЬНОГО КОМПОНЕНТУ ПРОФЕСІЙНОЇ ФІЗИЧНОЇ ГОТОВНОСТІ СТУДЕНТІВ АГРАРНИХ СПЕЦІААЬНОСТЕЙ}

\section{А. В. Сахненко}

Найбільшою иінністю відповідно до основних прав людини є ї̈ життя та здоров'я. Основи процесу фрормування гармонійно розвиненої особистості майбутнього фрахівия агропромислового сектору закладаються у вищій школі. Його фрундаментальними аспектами є: зміинення здоров'я, негативне ставлення до шкідливих звичок, формування системи здорового способу життя, досягнення високої та стійкої праиездатності через заняття фрізичною культурою $i$ спортом. I саме тому особливого значення набуває акмеологічна складова формування та збереження здоров'я, оскільки воно набуває більш глибокого сенсу в контексті вирішення сучасних завдань суспільства $i$, насамперед, розвитку людини, ї фрізичних можливостей, духовного потенціалу тощо. Визнані фрахівиі в галузі психології розвитку та акмеології приділють велику увагу стану здоров'я людини, від якого, безумовно, залежить формування гармонійної особистості та досягнення нею "акме", тобто вершини свого розвитку.

у представленій статті розглянуто акмеологічні засади професійно орієнтованого фізичного виховання студентів аграрних спеціальностей. Визначено структуру професійної фрізичної готовності фрахівиів аграрної промисловості, що включає когнітивний, фрізичний та здоров'язбережувальний компоненти.

У педагогічному експерименті брали участь студенти аграрних спеціальностей у загальній кількості 100 осіб.

Для визначення рівня фрізичного здоров'я студентства було застосовано методику Г. А. Апанасенка. У результаті проведеного дослідження було виявлено позитивний вплив акмеологічної складової професійно орієнтованого фрізичного виховання на формування здоров'язбережувального компоненту профресійної фрізичної готовності студентів аграрних спеціальностей. Середній показник індексу соматичного здоров'я в експериментальній групі покращився на 9,1 бала $і$ за якісними оцінками відповідав середнъому рівню фрізичного здоров'я. На кіниевому етапі дослідження студентів із низьким та нижче середнього рівнем фрізичного здоров'я серед представників експериментальної групи виявлено не було.

Ключові слова: акмеологія, здоров'я, акмеологічні засади, технології, рівень, показник, профресійно орієнтоване, професійна фрізична готовність, компонент, здоров'язбережувальний, студенти аграрних спеиіальностей.

Introduction of the issue. Modern science in the field of physical culture provides an integrated assessment of human health, associated with its components multifactorial and syncretic nature: physical activity level, genetics, gender, energy potential, learning conditions and lifestyle. And in this context, the main elements of health strengthening of the future professionals' generation in various industries and non-productive areas are students' physical culture, sports and social orientation to the healthy lifestyle. The process foundations of forming a harmoniously developed personality of the future specialist are laid in the high school. First of all, it is the health promotion, achieving high and sustainable performance through exercise, recreation and sports [12].

Considering the process of professionally - oriented physical education of students of agricultural higher educational institutions in the context of acmeological approach, it can be argued that its main purpose is formation an appropriate professional fitness level of future professionals to achieve professional acme, characterized by the higher degree of professionalism.

Acmeology studies professionalism as the highest stage of human development, which examines the problems and contradictions between 
the growing amount of information, on the one hand, and the time, required to master it, on the other [14].

Modern scientists define the acmeology objects as a person who reaches the higher development level, high potentials and top achievements of various subjects of social activity. The subject is subjective and objective factors that contribute or hinder the mature personality progressive development, and mechanisms that provide the opportunity to achieve the highest level of its development - acme [14].

A thorough analysis of scientific sources shows that, despite the large number of scientific acmeologists works, the problem of the health-preserving component formation of professional physical fitness of future specialists in the agricultural industry remains poorly reviewed.

The work was performed in accordance with the consolidated plan of research work of Theory and Methods of Physical Culture Department of A. S. Makarenko Sumy State Pedagogical University for 2016-2020 on the scientific theme "Theoretical and methodological foundations of physical education of different groups" (state registration number 0116U000900).

Current state of the issue. Scientific literature analysis $[6 ; 10]$ allowed to define professional physical fitness as an integrative personal education, which includes various components: a set of knowledge, the level of development of professionally important physical qualities and physical health, adequate to the future profession requirements and content. Revealing the professional physical fitness structure of agricultural specialties students, the following components - cognitive, physical and health have been identified [15].

The health component of professional physical fitness characterizes the physical health state of the agricultural industry future specialist. Its indicator is the level of physical health. It should be stressed that the basis for the formation and development of the successful specialist's personality is the proper health level, including physical. It is the formation and maintenance of the proper physical health level that provides the acmeological principles of the organization of students' professionally oriented physical education.

According to the classification proposed by M. S. Goncharenko, the health technologies composition includes physical culture and health technologies and technologies to ensure the life safety $[2 ; 11]$. In addition, scientists have proven the positive impact of physical education on the students' physical health $[3-5 ; 7 ; 9 ; 11 ; 13]$. Thus, it can be argued about the ratio of cognitive, physical and health components and their complex impact on the formation of the proper physical health level, as the basis of professional physical fitness of agricultural specialties students.

According to scientists S. P. Kost and V. P. Yasinsky, the development of health (physical, mental, moral) personality and the healthy environment creation is impossible without the acmeological component and are realized at the following levels: value-motivational, which is manifested in desire to maintain health, activity, purposefulness; behavioral, which is characterized by the enthusiasm degree for the healthy lifestyle, their activities, the need for movement; reflexive-evaluative, which reflects the ability to assess and understand their inner world state; emotional-sensory, which reflects the ability to self-control, the ability to control their feelings and emotions; cognitive means the desire to learn about the healthy lifestyle conditions; ethnofunctional, which characterizes the holistic man's health from the standpoint of ethnodifferential and ethnointegrative features [8].

Outline of the unresolved issues brought up in the article. Insufficient research on the impact of the acmeological component on the formation of the health-preserving 
component of professional physical fitness of agricultural specialties students led to the choice of our study direction.

Aim of research. The aim of our study was to examine the effectiveness of the acmeological component of professionally oriented physical education in the formation of the appropriate physical health level of agricultural specialties students.

Research methods. On the one hand, are based on theoretical and methodological procedure of analyzing the problem field of the research by moving from the general to the specific, that is, from theoretical aspects of the problem field to its practical aspects. On the other hand, the researching process presupposes the extrapolation procedure of system-theoretical reduction and simplification of the analyzed phenomena. Among the research methods there are the analysis and pedagogical experiment that help to unify the acmeological principles of health-preserving component formation of professional physical readiness of agricultural specialties students.

Results and discussion. The study involved students of Agronomy and Nature Management Faculty of Sumy National Agrarian University in a total of 100 people, who were classified in the main group for health reasons. The control and experimental groups included 50 young men. The pedagogical experiment lasted for two academic years and covered the period from September 2017 to June 2018.

However, 336 hours of classes were planned for students of the control and experimental groups during two study years -224 of them were classroom and 112 were independent. The workload for the academic year was 168 academic hours, 112 of which were classroom classes, and 56 - independent. The weekly workload in both groups was six academic hours: four of them classroom classes, two - independent, lasting 2 academic hours for each.
Classroom classes of the experimental group depending on the tasks, methods and tools were divided into lectures, practical and interactive. In addition to lectures, students were provided with theoretical knowledge in practical and interactive classes, as well as individual explanations and recommendations for conducting independent classes on professionally oriented physical education. Individual organizational class forms were not planned in the workload and were related to organizational and educational work. Such classes were held as needed. Their main task was to work with students who missed classes or lagged behind classmates in terms of one of the three components of professional fitness. Usually, the weekly workload of individual classes ranged from two to four academic hours, the schedule was determined separately by each teacher. Interactive classes were planned in a network of classroom classes and alternated with practical ones.

In order to form a health-preserving component during the experiment, developing acmeological technologies were used. Among them - selfdevelopment technologies and psychotechnologies aimed at the development of man's motivational, cognitive, emotional and moral spheres.

The use of self-development technologies took place during independent classes and involved the performance of individual tasks and the development of complexes of physical exercises aimed at improving the health and physical performance of agricultural industry future specialists. Individual tasks stimulated the discovery of a creative approach to their solution and the development of reflection.

Psycho-technologies

were implemented during practical, interactive classes, sports and mass work were provided for the use of game and competitive teaching methods. Within the framework of these methods, mobile games, sports games, relay races and 
competitions in individual and team sports were carried out, which contributed to the development of moral and volitional qualities and communication skills, theoretical knowledge and motivation to improve and maintain students' health and selfimprovement.

The acmeological basis of professionally oriented physical education has led to the creation of a number of the following pedagogical conditions necessary for the formation of a health-preserving component of professional physical fitness of the agroindustrial complex future specialists:

- cognitive activity intensification and the motivation level increase;

- the information environment improvement;

- stimulating the development of reflection and self-control.

Solving health problems, in accordance with acmeological principles, involves the acquisition of theoretical knowledge about safety rules during exercise and at work, methods of self-control, the formation of values for the healthy lifestyle and disease prevention, the formation and maintenance of proper health - as a result of professionally oriented physical education. Thus, as a result of professionally oriented physical education classes, agricultural specialties students have to:

- have a significant amount of theoretical material on professionally oriented physical training, specialists' safety and working conditions features in the agro-industrial complex.

- to master the amount of knowledge in the field of physical culture and sports (knowledge of basic concepts definitions, development methods of physical qualities, etc.);

- know the performing exercises technique of professionally oriented and general physical training;

- be able to independently compose complexes of morning and industrial gymnastics in the chosen specialty direction;

- know the basic tools and principles of training for professionally oriented and general physical training;

- be able to properly select tools and dose the load, using methods of selfcontrol, for independent physical education classes;

- know the basics of the healthy lifestyle, the negative impact on the body of bad habits;

- be able to organize activities of active recreation in free time from study and work.

- have an appropriate level of professionally-oriented physical fitness (not below average);

- have a proper level of physical health (not below average);

- have an appropriate level of professional physical fitness (not less than sufficient).

The effectiveness verification of the formation of the health-preserving component of professional physical fitness was carried out at the initial and final stages of the pedagogical experiment by the rapid assessment method of the somatic health level after G. L. Apanasenko [1]. At the beginning of the experiment, the control and experimental groups had no significant differences in somatic health.

Studies of students' anthropometric and physiometric indicators at the initial stage of the formative experiment (Table 1) suggest that these indicators quantitative values in both groups correspond to the age norms of young men development. The average body length was $175,70 \pm 0,77 \mathrm{~cm}$. in the control group and $174,98 \pm 0,87 \mathrm{~cm}$. in the experimental group. The body weight of the control group was $73,5 \pm$ 0,8 , in the experimental group $-72,8 \pm$ $0,81 \mathrm{~kg}$. There was no significant difference between the average students' height and weight in the control and experimental groups $(\mathrm{p}>0,05)$. 
Anthropometric and physiometric indicators of students within control and experimental groups at the initial stage of the formative experiment $(\bar{x} \pm \mathbf{S} \bar{x})$

\begin{tabular}{|l|c|c|}
\hline \multicolumn{1}{|c|}{ Indicator } & Control group & Experimental groups \\
\hline Body length, $\mathrm{cm}$ & $175,70 \pm 0,77$ & $174,98 \pm 0,87$ \\
\hline Body weight, $\mathrm{kg}$ & $73,5 \pm 0,8$ & $72,8 \pm 0,81$ \\
\hline Vital capacity, ml. & $3921,2 \pm 24,82$ & $3995,8 \pm 39,21$ \\
\hline Grip strength, kg & $40,64 \pm 0,42$ & $41,54 \pm 0,39$ \\
\hline Heart rate, beats / min. & $77,98 \pm 0,27$ & $78,3 \pm 0,26$ \\
\hline BP, mmHg. & $117,8 \pm 0,25$ & $117,1 \pm 0,34$ \\
\hline
\end{tabular}

The average values of lungs vital capacity in the control group were $3921,2 \pm 24,82 \mathrm{ml}$., In the experimental - 3995,8 $\pm 39,21 \mathrm{ml}$. There was no significant difference between $\mathrm{CG}$ and EG $(p>0,05)$. The average values of grip strength in the control group were $40,64 \pm 0,42 \mathrm{~kg}$, in the experimental group - 41,54 $\pm 0,39 \mathrm{~kg}$ and did not differ significantly $(p>0,05)$. The heart rate of students was within normal limits and was $77,98 \pm 0,27$ beats / min in the control and $78,3 \pm 0,26$ beats / $\mathrm{min}$ in the experimental groups. There was no significant difference between these indicators of both groups $(p>0,05)$. The average values of systolic blood pressure corresponded to the studied age norms of physical development and amounted to $117,8 \pm$ $0,25 \mathrm{mmHg}$. in the control group and $117,1 \pm 0,34 \mathrm{mmHg}$ in the experimental group, $(\mathrm{p}>0,05)$.

The average values of the somatic health index and its components are given in the table (Table 2).

At the initial stage of our study, it was found that the average body weight index in the control group was $23,8 \pm$ $0,12 \mathrm{~kg} / \mathrm{m}^{2}$, in the experimental group - $23,7 \pm 0,13 \mathrm{~kg} / \mathrm{m}^{2}$, no significant difference between the indicators was found $(p>0,05)$. The average points of this indicator on the assessment scale of the somatic health level after G. L. Apanasenko was 0 points and $-0,04 \pm$ 0,03 points in the control and experimental groups, respectively.

Table 2

\section{Average values of quantitative indicators of the somatic health level and its components of agricultural students at the initial stage of the formative} experiment $(\bar{x} \pm \mathbf{S} \bar{x})$

\begin{tabular}{|l|c|c|c|c|}
\hline \multirow{2}{*}{ Indicators } & \multicolumn{2}{|c|}{$\mathbf{C G ( n = 5 0 )}$} & \multicolumn{2}{c|}{ EG(n = 50) } \\
\cline { 2 - 5 } & $\begin{array}{c}\text { Average } \\
\text { values }\end{array}$ & Points & $\begin{array}{c}\text { Average } \\
\text { values }\end{array}$ & Points \\
\hline $\begin{array}{l}\text { Body weight } \\
\text { index, kg/m² }\end{array}$ & $23,8 \pm 0,12$ & 0 & $23,7 \pm 0,13$ & $-0,04 \pm 0,03$ \\
\hline $\begin{array}{l}\text { Vital capacity } \\
\text { index, ml/kg }\end{array}$ & $53,55 \pm 0,39$ & $0,2 \pm 0,09$ & $55,03 \pm 0,43$ & $0,4 \pm 0,09$ \\
\hline $\begin{array}{l}\text { Strength } \\
\text { index, \% }\end{array}$ & $55,5 \pm 0,52$ & $-0,96 \pm 0,03$ & $57,2 \pm 0,42$ & $-0,9 \pm 0,04$ \\
\hline $\begin{array}{l}\text { Robinson } \\
\text { index, CI }\end{array}$ & $91,8 \pm 0,37$ & $-0,16 \pm 0,05$ & $91,6 \pm 0,38$ & $-0,14 \pm 0,05$ \\
\hline $\begin{array}{l}\text { Martine probe, } \\
\text { s }\end{array}$ & $141,4 \pm 1,58$ & $1,3 \pm 0,1$ & $143,4 \pm 2,07$ & $1,3 \pm 0,13$ \\
\hline $\begin{array}{l}\text { Somatic health } \\
\text { index, points }\end{array}$ & \multicolumn{2}{|c|}{$0,4 \pm 0,15$} & \multicolumn{2}{c|}{$0,6 \pm 0,23$} \\
\hline
\end{tabular}


The mean values of the vital capacity index were $53,55 \pm 0,39 \mathrm{ml} / \mathrm{kg}$ in the control group and $55,03 \pm 0,43 \mathrm{ml} / \mathrm{kg}$ in the experimental group. The average values of quantitative estimates for this indicator were $0,2 \pm 0,09$ points in the control group and $0,4 \pm 0,09$ points in the experimental group.

The average strength index in the control group was $55,5 \pm 0,52 \%(-0,96 \pm$ 0,03 points), in the experimental $-57,2$ $\pm 0,42 \%(-0,9 \pm 0,04$ points) and did not differ significantly $(\mathrm{p}>0,05)$.

The average values of Robinson index at the initial stage of the formative pedagogical experiment were significantly equal in both groups $(p>0.05)$ and amounted to $91,8 \pm 0,37$ CI $(-0,16 \pm 0,05$ points $)$ in students of the control group and $91,6 \pm 0,38$ CI ($0,14 \pm 0,05$ points) in the experimental group.

As a result of statistical processing of data obtained after MartineKushelevsky test, the average values of this indicator were determined. They were $141,4 \pm 1,58 \mathrm{~s}(1,3 \pm 0,1$ points $)$ in the control group and $143,4 \pm 2,07 \mathrm{~s}$
$(1,3 \pm 0,13$ points) in the experimental group. No significant difference was found between both groups indicators $(\mathrm{p}>0,05)$.

The average indicators of students' somatic health index of the control and experimental groups at the initial stage of the pedagogical experiment did not differ significantly and amounted to 0,4 $\pm 0,15$ points in the control and $0,6 \pm$ 0,23 points in the experimental group. Quantitative values of the somatic health index in both groups corresponded to low physical health levels.

Among the students of the experimental group, the average somatic health level was recorded in $2 \%$ of young men, below the average level - 6\%, a low level was found in $92 \%$ of students. In the control group, below-average levels were found in $2 \%$ of youth, $98 \%$ showed low levels.

The analysis of anthropometric indicators at the final stage of the formative experiment allows us to state that the body length indicators in both groups remained unchanged (Table 3 ).

Dynamics of anthropometric and physiometric indicators of agricultural

Table 3 students during the formative experiment $(\bar{x} \pm \mathbf{S} \bar{x})$

\begin{tabular}{|c|c|c|c|c|}
\hline \multirow[t]{2}{*}{ Indicator } & \multicolumn{2}{|c|}{$\mathbf{C G}$} & \multicolumn{2}{|c|}{ EG } \\
\hline & initial & final & initial & final \\
\hline $\begin{array}{l}\text { Body length, } \\
\mathrm{cm}\end{array}$ & $175,70 \pm 0,77$ & $175,70 \pm 0,77$ & $174,98 \pm 0,87$ & $174,98 \pm 0,87$ \\
\hline \multirow{2}{*}{$\begin{array}{l}\text { Body weight, } \\
\text { kg }\end{array}$} & \multirow[t]{2}{*}{$73,5 \pm 0,8$} & \multirow[t]{2}{*}{$74,1 \pm 0,77$} & $72,8 \pm 0,81$ & $69,04 \pm 0,92$ \\
\hline & & & \multicolumn{2}{|c|}{$* * \mathrm{t}=3,07$} \\
\hline \multirow{2}{*}{$\begin{array}{l}\text { Vital capacity, } \\
\text { ml. }\end{array}$} & $3921,2 \pm 24,82$ & $3995,6 \pm 24,43$ & $3995,8 \pm 39,21$ & $4408,4 \pm 33,97$ \\
\hline & \multicolumn{2}{|c|}{${ }^{*} \mathrm{t}=2,14$} & \multicolumn{2}{|c|}{$* * \mathrm{t}=7,95$} \\
\hline \multirow{2}{*}{$\begin{array}{l}\text { Grip strength, } \\
\text { kg }\end{array}$} & $40,64 \pm 0,42$ & $42,70 \pm 0,33$ & $41,54 \pm 0,39$ & $48,60 \pm 0,4$ \\
\hline & \multicolumn{2}{|c|}{$*_{\mathrm{t}}=3,86$} & \multicolumn{2}{|c|}{$* * \mathrm{t}=12,64$} \\
\hline \multirow{2}{*}{$\begin{array}{l}\text { Heart rate, } \\
\text { beats / min. }\end{array}$} & $77,98 \pm 0,27$ & $73,50 \pm 0,39$ & $78,3 \pm 0,26$ & $69,20 \pm 0,28$ \\
\hline & \multicolumn{2}{|c|}{$*_{\mathrm{t}}=9,44$} & \multicolumn{2}{|c|}{${ }^{* *} \mathrm{t}=23,82$} \\
\hline \multirow[t]{2}{*}{$\mathrm{BP}, \mathrm{mmHg}$} & $117,8 \pm 0,25$ & $116,9 \pm 0,28$ & $117,1 \pm 0,34$ & $112,7 \pm 0,28$ \\
\hline & \multicolumn{2}{|c|}{${ }^{*} \mathrm{t}=2,40$} & \multicolumn{2}{|c|}{$* * t=9,99$} \\
\hline
\end{tabular}

Notes: * - the significant difference between the indicators of control groups before and after the pedagogical experiment at $\mathrm{p}<0,05,\left(\mathrm{t}_{\text {crit }}=1,987\right) ;{ }^{* *}-$ 
Вісник Житомирсъкого державного иніверситети імені Івана Франка. Педагогічні науки. Bun. 2 (101)

the significant difference between the indicators of the experimental group before and after the pedagogical experiment at $\mathrm{p}<0,05$, $\left(\mathrm{t}_{\mathrm{crit}}=1,987\right)$.

Significant differences between the indicators of the control group at the initial and final stage of the pedagogical experiment, were not presented, but amounted to $0,6 \mathrm{~kg}(0,81 \%)$. In the experimental group, the average value was lost weight of $3,76 \mathrm{~kg}(5,2 \%), \mathrm{t}=$ 3,07 (at $\mathrm{p}<0,05$ ) (Fig. 1). At the final stage, the difference between the body weight of students in the control and experimental groups was $5,06 \mathrm{~kg}$ $(6,8 \%), t=4,22($ at $p<0,05)$.

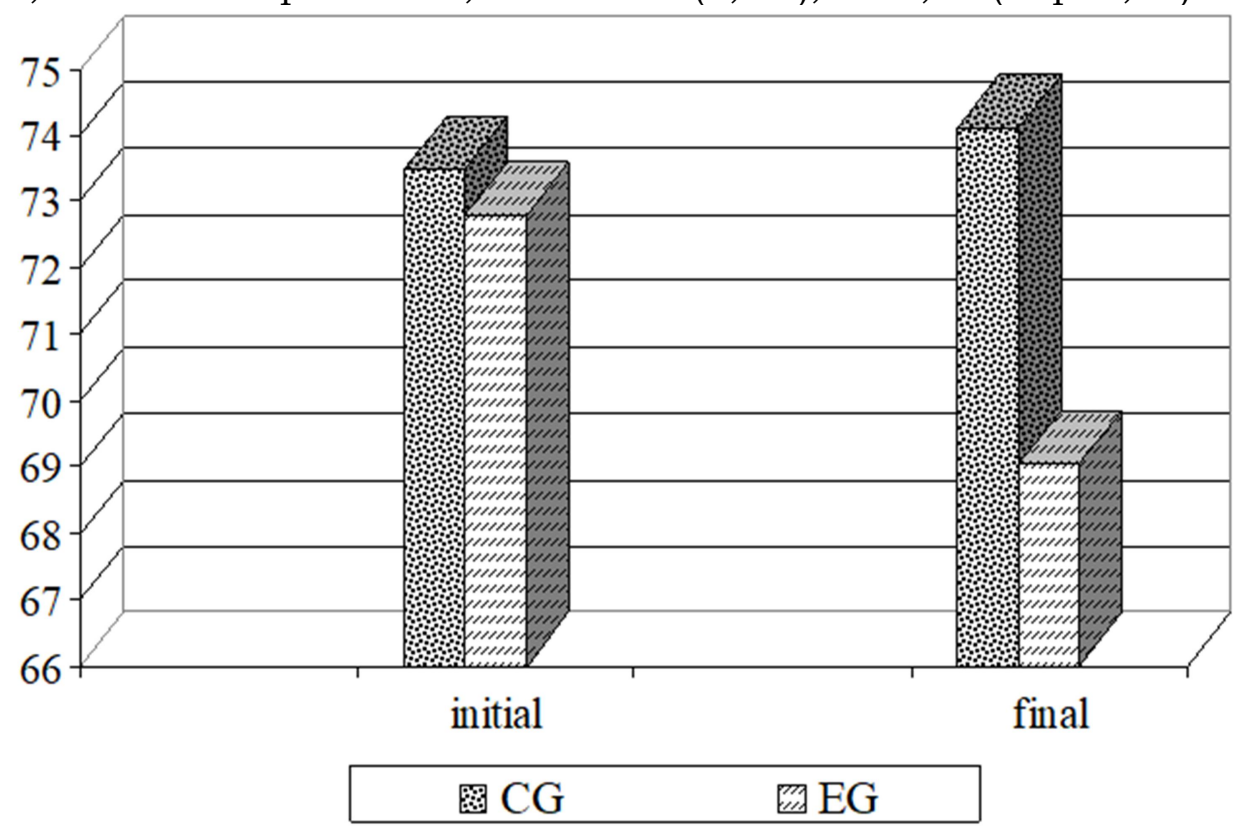

\section{Fig. 1. Dynamics of body weight of agricultural specialties students at the beginning and end of the formative experiment}

Analysis of lungs vital capacity showed the following results: the improvement in the experimental group is $412,6 \mathrm{ml}$. $(9,4 \%), \mathrm{t}=7,95(\mathrm{p}<0,05)$; in the control group - 74,4 ml. (1,9\%), $\mathrm{t}=2,14 \quad(\mathrm{p}<0,05)$. The significant difference between the performance of students in the experimental and control groups after the experiment was $412,8 \mathrm{ml}(9,4 \%)$.

As the experiment result, the indicators of grip strength in the experimental group significantly improved by $7,06 \mathrm{~kg}$, an increase of $14,5 \%$. In the control group, the improvement is $2,06 \mathrm{~kg}$, the increase was $4,8 \%$. The difference between the final results of the experimental and control groups is $5,9 \mathrm{~kg}(12,1 \%)$.

In terms of heart rate, the improvement in the experimental group was 9,1 beats $/ \min (11,6 \%)$, in the control group - by 4,48 beats/min $(5,8 \%)$. The indicators of the experimental group compared to the indicators of the control at the final stage improved by 4,3 beats $/ \mathrm{min}$.

Analysis of systolic blood pressure suggests that at the final stage of the study, the students' performance in the experimental group was significantly lower than that of students in the control group by $4,2 \mathrm{mmHg}$. (3,6 \%) The difference between the initial and final indicators of BP among the young men of the experimental group is $4,4 \mathrm{mmHg}$. $(3,8 \%)$, among students of the control group - 0,9 mmHg. (0,8 \%).

As a result of statistical processing of the study data, the indicators dynamics of the somatic health index components in both groups was revealed (Table 4). 
Changes in the indicators of somatic health index and its components among agricultural specialties students during the formative experiment $(\bar{x} \pm \mathbf{S} \bar{x})$

\begin{tabular}{|c|c|c|c|c|}
\hline \multirow[b]{2}{*}{ Indicators } & \multicolumn{2}{|c|}{$\mathbf{C G}(\mathbf{n}=50)$} & \multicolumn{2}{|c|}{$\mathbf{E G}(\mathbf{n}=50)$} \\
\hline & $\begin{array}{l}\text { Average } \\
\text { values }\end{array}$ & Points & $\begin{array}{l}\text { Average } \\
\text { values }\end{array}$ & $\begin{array}{l}\text { Average } \\
\text { values }\end{array}$ \\
\hline \multirow{2}{*}{$\begin{array}{l}\text { Body weight } \\
\text { index, } \mathrm{kg} / \mathrm{m}^{2}\end{array}$} & \multirow[t]{2}{*}{$23,8 \pm 0,12$} & \multirow[t]{2}{*}{$23,97 \pm 0,09$} & $23,7 \pm 0,13$ & $22,5 \pm 0,1$ \\
\hline & & & \multicolumn{2}{|c|}{$* * \mathrm{t}=7,32$} \\
\hline \multirow{2}{*}{$\begin{array}{l}\text { Vital capacity } \\
\text { index, } \mathrm{ml} / \mathrm{kg}\end{array}$} & \multirow[t]{2}{*}{$53,55 \pm 0,39$} & \multirow[t]{2}{*}{$54,13 \pm 0,39$} & $55,03 \pm 0,43$ & $64,2 \pm 0,61$ \\
\hline & & & \multicolumn{2}{|c|}{$* * \mathrm{t}=12,29$} \\
\hline \multirow{2}{*}{ Strength index, \% } & $55,5 \pm 0,52$ & $57,8 \pm 0,48$ & $57,2 \pm 0,42$ & $70,8 \pm 0,74$ \\
\hline & \multicolumn{2}{|c|}{${ }^{*} \mathrm{t}=3,25$} & \multicolumn{2}{|c|}{$* * \mathrm{t}=15,98$} \\
\hline \multirow{2}{*}{$\begin{array}{l}\text { Robinson index, } \\
\text { CI }\end{array}$} & $91,8 \pm 0,37$ & $85,9 \pm 0,54$ & $91,6 \pm 0,38$ & $77,8 \pm 0,4$ \\
\hline & \multicolumn{2}{|c|}{$*_{\mathrm{t}}=9,01$} & \multicolumn{2}{|c|}{$* * \mathrm{t}=25,01$} \\
\hline \multirow[t]{2}{*}{ Martin probe, $\mathrm{s}$} & $141,4 \pm 1,58$ & $127,9 \pm 1,85$ & $143,4 \pm 2,07$ & $104,5 \pm 1,56$ \\
\hline & \multicolumn{2}{|c|}{${ }^{*} \mathrm{t}=5,55$} & \multicolumn{2}{|c|}{$* * \mathrm{t}=15,01$} \\
\hline \multirow{2}{*}{$\begin{array}{l}\text { Somatic health } \\
\text { index, points }\end{array}$} & $0,4 \pm 0,15$ & $1,98 \pm 0,32$ & $0,6 \pm 0,23$ & $9,7 \pm 0,24$ \\
\hline & \multicolumn{2}{|c|}{$* \mathrm{t}=4,47$} & \multicolumn{2}{|c|}{$* * t=27,38$} \\
\hline
\end{tabular}

Notes: * - the significance of the difference between the indicators of students in the control group before and after the pedagogical experiment at $\mathrm{p}<0,05, \quad\left(\mathrm{t}_{\text {crit }}=1,987\right) ; \quad * * \quad-\quad$ the significance of the difference between the indicators of the students of the experimental group before, after the pedagogical experiment at $\mathrm{p}<0,05$, $\left(t_{\text {crit }}=1,987\right)$.

The final stage results of the pedagogical experiment showed a significant positive trend in all indicators of somatic health index in the experimental group.

The difference between the initial and final values of the body weight index in the experimental group is 1,2 $\mathrm{kg} / \mathrm{m}^{2}$ in the control $-0,2 \mathrm{~kg} / \mathrm{m}^{2}$.

According to the vital index, which characterizes the reserve of functions of external human respiration, the improvement in the experimental group was $9,17 \mathrm{ml} / \mathrm{kg}(14,3 \%)$, in the control - $0,58 \mathrm{ml} / \mathrm{kg}(1,1 \%)$. The difference between the parameters of the experimental and control groups at the final stage was $10,07 \mathrm{ml} / \mathrm{kg}(15,7 \%)$, $\mathrm{t}=13,91$ (at $\mathrm{p}<0,05)$. The average point on the vital index was $2,2 \pm 0,1$ points $i$
$0,3 \pm 0,09$ points in the experimental and control groups, respectively.

The power index dynamics gives the right to say that during the formative experiment there was a significant increase in its quantitative characteristics in the experimental and control groups. The experimental group indicators improved by $13,6 \%$, in the control group the difference was determined by $2,3 \%$. The difference between the quantitative values of the final results is $13 \%, t=14,74$ (at $\mathrm{p}<0,05)$. The average values of points on this indicator at the final stage were $1,34 \pm 0,12$ points in the experimental and $-0,8 \pm 0,08$ points in the control group.

Changes in the Robinson index among the students of the experimental group show a significant improvement in the values of the final study stage compared to the initial, which is 13,8 CI $(15,1 \%)$. Among the young men of the control group, this figure improved by 5,9 units. $(6,4 \%)$. The difference between the final indicators of the experimental and control groups is 8,1 $\mathrm{CI}, \mathrm{t}=12,05($ at $\mathrm{p}<0,05)$. 
The recovery time after exercise within the Martin Kushelevsky probe among the young men of the experimental group decreased by 38,9 $\mathrm{s}$, which is $27,1 \%$. In the control group, the recovery time decreased by $13,5 \mathrm{~s}(9,6 \%)$. The difference between the indicators of both groups at the final stage is $23,4 \mathrm{~s}(18,3 \%), \mathrm{t}=9,67$ (at $\mathrm{p}<0,05$ ).

Statistical data processing allows us to draw conclusions about the physical health level of agricultural students. Among the students in the experimental group, $16 \%$ of young men were found to be above average, and
$84 \%$ of students showed average physical health. In the control group, the average level was determined in $2 \%$ of students, $24 \%$ had indicators below the average level, $74 \%$ had a low level of physical health.

According to the study results, the average somatic health index in the experimental group improved by 9,1 points, $p<0,05$, and corresponds to the average physical health level. The control group indicator, compared to the initial, increased by 1,58 points, $\mathrm{p}<0,05$ and is quantitatively within the low physical health level (Fig. 2).

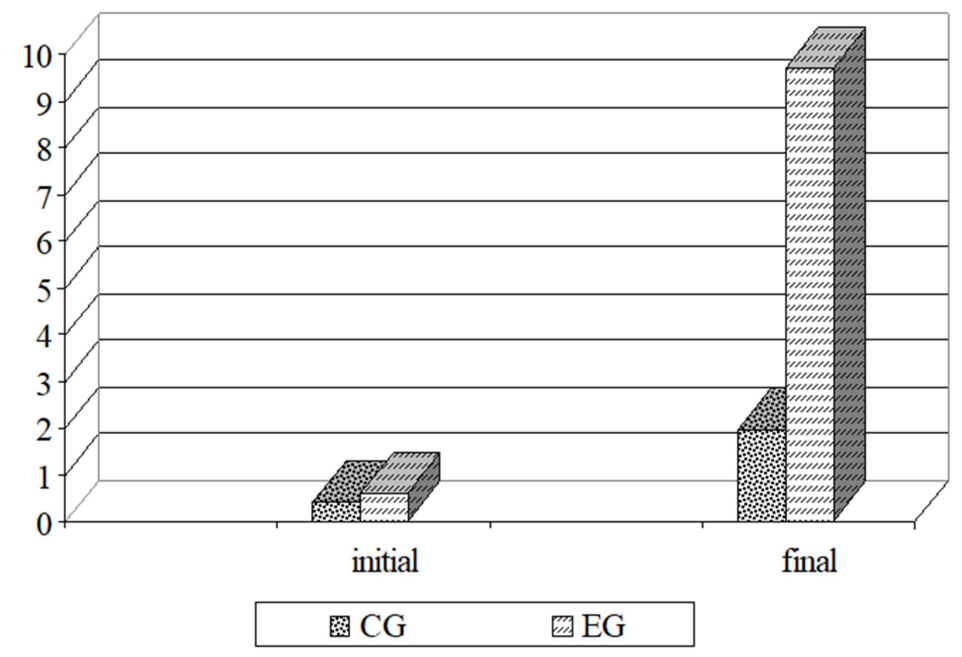

\section{Fig. 2. Dynamics of the physical health level of the agricultural industry future specialists during the formative experiment}

\section{Conclusions and research} perspectives. Studies of the somatic health level allow us to assert the positive impact of the use of acmeological technologies on the formation of the health-preserving component of professional physical fitness of agricultural specialties students. Among the young people of the experimental group during the pedagogical experiment, the positive dynamics is observed for all indicators. The average somatic health index, which was in the low quantitative range at the beginning of the experiment, eventually corresponded to the average physical health level. It should be noted that at the final study stage, students with low and below average physical health were not found among the experimental group.

Changes in the students' performance in the control group were insignificant. The average quantitative health index in terms of quantitative characteristics at the beginning and end of the experiment was within the low physical health level. The vast majority of the control group at the end of the study had indicators corresponding to the low level. Indicators of high and above average level in the control group were not recorded. 
Prospective directions for the study were due to the small number of studies in the field of the impact of the acmeological component of the educational process on students' physical education of agricultural higher educational institutions on the formation of a comprehensively developed personality of a specialist in the agricultural industry. Our further explorations will lie in the field of identifying the impact of the use of acmeological technologies on the formation of professional physical fitness and acmeological competence of agricultural sector future specialists of our country.

\section{REFERENCES (TRANSLATED \& TRANSLITERATED)}

1. Apanasenko, G.L. Evolyutsiya bioenergetiki $i$ zdorove cheloveka [The evolution of bioenergy and human health]. Sank-Peterburg: MGP Petropolis [in Russian].

2. Honcharenko, M.S., $\&$ Luparenko, S.Ye. (2010). Poniattia "valeopedahohika" ta "pedahohichna valeolohiia" u psykholohopedahohichnii literaturi [The concept of "valeopedagogy" and "pedagogical valeology" in the psychological and pedagogical literature]. Pedahohichni nauky: teoriia, istoriia, innovatsiini tekhnolohii - Pedagogical Sciences: theory, history, innovation technologies, 1 (3), 30-38 [in Ukrainian].

3. Hryban, H.P. (2012). Fizychne vykhovannia studentiv ahrarnykh vyshchykh navchalnykh zakladiv [Physical education of agricultural higher educational institutions students]. Zhytomyr: Ruta [in Ukrainian].

4. Deminska, L.O. (2012). Fizychne zdorovia uchnia yak holovna tsinnist pedahohichnoho protsessu [Students' physical health as the main value of the pedagogical process]. Pedahohika, psykholohiia ta medyko-biolohichni problemy fizychnoho vykhovannia $i$ sportu - Pedagogy, psychology and medical and biological problems of physical education and sports, 54-58 [in Ukrainian].

5. Dubohai, O.D. (2004). Faktory, yaki vyznachaiut efektyvnist fizychnoho vykhovannia studentiv spetsialnoi medychnoi hrupy [Factors that determine the effectiveness of students' physical education of the special medical group]. Aktualni problemy rozvytku rukhu "Sport dlia vsikh" u konteksti yevropeiskoi intehratsii Ukrainy - Actual problems of the movement development "Sport for All" in the context of European integration of Ukraine, 370-374 [in Ukrainian].

6. Duray-Novakovskaya, K.M.

(1983) Osnovyi i zakonomernosti protsessa

professionalnoy

pedagogicheskoy formirovaniya [Fundamentals and regularities of the formation process of professional readiness for pedagogical activity]. Extended abstract of Doctor's thesis. Moskow [in Russian].

7. Kanishevskyi, S.M., Ozerova, O.A. (2015). Znachennia fizychnoho vykhovannia studentstva Ukrainy $\mathrm{v}$ suchasnykh umovakh [The value of Ukrainian students physical education in modern conditions.]. Aktualni problemy fizychnoho vykhovannia $i$ sportu $v$ suchasnykh umovakh - Actual problems of physical education and sports in modern conditions, 132-137 [in Ukrainian].

8. Kost, S.P., \& Yasinskyi, V.P. (2015). Zdoroviazberihaiucha kontseptsiia u konteksti akmeolohichnoho pidkhodu: teoretychnyi aspekt [Health concept in the context of acmeological approach: theoretical aspect]. Naukovi zapysky Kirovohradskoho derzhavnoho pedahohichnoho universytetu imeni Volodymyra Vynnychenka. Seriia: Pedahohichni nauky - Scientific notes of Kirovohrad State Pedagogical University named after Volodymyr Vynnychenko. Series: Pedagogical Sciences, vyp. 135, 131-135 [in Ukrainian]. 
9. Kuryliuk, Yu.I.

(2017). Znachennia fizychnoi aktyvnosti $u$ formuvanni profesiinoho dovholittia maibutnikh pedahohiv [The importance of physical activity in the formation of professional longevity of future teachers]. Young Scientist, t. 43, 3(1), 183-186 [in Ukrainian].

10. Mazur, N.P. (2013). Poniattia "hotovnosti" ta vyznachennia strukturnykh komponentiv hotovnosti maibutnikh uchyteliv informatyky [The concept of "readiness" and the definition of readiness structural components of future computer science teachers]. Naukovi zapysky. Seriia: Pedahohichni nauky - Scientific Proceedings. Series: Pedagogical sciences, 121, 288-292 [in Ukrainian].

11. Rybalko, L.M.

(2017).

Pedahohichni umovy formuvannia zdorovoho sposobu zhyttia v studentskoi molodi [Pedagogical conditions for the formation of the healthy lifestyle in student youth]. Visnyk Chernihivskoho natsionalnoho pedahohichnoho universytetu imeni T. H. Shevchenka. Seriia: Pedahohichni nauky. Fizychne vykhovannia ta sport Bulletin of Chernihiv National Pedagogical University named after T. G. Shevchenko. Series: Pedagogical Sciences. Physical education and sports, vyp. 147, t. II, 118-121 [in Ukrainian].

12. Rubanenko, A.V.

(2017). Psykhofiziolohichni aspekty profesiinoprykladnoi fizychnoi pidhotovky studentiv ahrarnykh spetsialnostei
[Psychophysiological aspects of professional and applied physical training of agricultural specialties students]. Visnyk Chernihivskoho natsionalnoho pedahohichnoho universytetu. Seriia: Pedahohichni nauky - Bulletin of Chernihiv National Pedagogical University. Series: Pedagogical sciences, 143, 238-241 [in Ukrainian].

13. Selivanov, Ye.V.

(2018).

Znachennia fizychnoi aktyvnosti studentskoi molodi u protsesi formuvannia osobystosti [The physical activity value of student youth in the process of personality formation]. Aktualni problemy fizychnoho vykhovannia riznykh verstv naselennia - Actual problems of physical education of different segments of the population, 220-226 [in Ukrainian].

14. Taran, O.V.

(2013). Akmeolohichna kompetentnist yak skladova profesionalizmu pedahoha [Acmeological competence as a component of teacher professionalism]. Doslidzhennia molodykh uchenykh $u$ konteksti rozvytku suchasnoi nauky Young scientists' research in the context of the modern science development, 153161 [in Ukrainian].

15. Sakhnenko, A.V. (2020). Structure of professional physical readiness of agricultural specialty students. Tendenze attuali della moderna ricerca scientifica, 2, 28-30 [in English].
Received: July 09, 2020 Accepted: August 05, 2020 